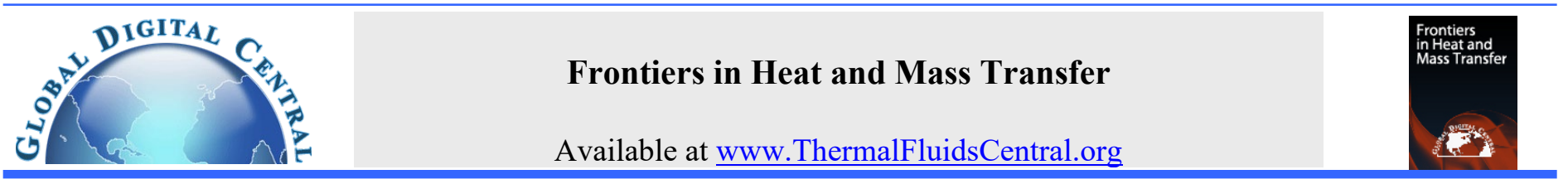

\title{
DRYING PERFORMANCE OF JACKFRUIT DODOL USING RICE HUSK ENERGY ON HOUSEHOLD IN LOMBOK, INDONESIA
}

\author{
Ida Bagus Alit, I Gede Bawa Susana* \\ Department of Mechanical Engineering, Faculty of Engineering, University of Mataram, Jl. Majapahit No. 62 Mataram-Nusa \\ Tenggara Barat 83125 Indonesia
}

\begin{abstract}
Rice husk is a cheap fuel source and it is abundantly available in Indonesia. The heat exchanger mechanism was used in other to, the dried material was not contaminated by the combustion gases. The drying system consists of three components which include the furnace, heat exchanger pipe, and drying chamber. The heat exchanger pipe connects the furnace with the drying chamber and transfers the heat generated from rice husk burning to the drying chamber. The drying chamber was the section for drying the jackfruit dodol. It consists of 4 shelves and is equipped with an exhaust fan. The results showed capable that the dryer decreases moisture faster than conventional methods. The moisture content of jackfruit $d o d o l$ reduced from $29 \%$ to $23.7 \%$ within 600 minutes and the average drying chamber efficiency was $25.3 \%$.
\end{abstract}

Keywords: dryers, rice husks, heat exchangers, jackfruit dodol

\section{INTRODUCTION}

Lombok is an Indonesian island located between Bali and Sumbawa. This is a tourism area with a small industrial centre for processing plantation products, especially the Jackfruit dodol, which is a traditional regional cake popular in the community. The fruit is processed into dodol to increase the sales value as well as extends its shelf life. Furthermore, the drying process is needed to preserve jackfruit dodol. The drying process is a method to preserve food ingredients to reduce spoilage and damage. Generally, this is carried out by placing the product directly under the sun or by using a dryer, in a drying room. However, both natural and artificial drying processes involve synchronous heat and mass exchange between the surrounding air and the granules. Furthermore, this process tends to reduce the moisture to a minimum level thereby ensuring its safety before consumption and storage (Delgado-Plaza et al., 2020). This also needs to be supported by adequate facilities. However, in most developing countries inappropriate storage and drying facilities tend to cause post-harvest losses to the agricultural sector (Nguimdo and Noumegnie, 2020). Therefore post-harvest handling is an important step adopted to maintain the quality of materials during storage (Buchori et al., 2013).

Several studies have been widely carried out on drying processes and ways of handling post-harvest losses. An instance is a gas-to-gas heat exchanger dryer designed using solid biomass to dry $2.5 \mathrm{~kg}$ of palm fiber (Yunus et al., 2011). The other drying process is anchovy using a heat exchanger with coconut coir fuel to produce an average temperature of $41.30^{\circ} \mathrm{C}$. This heat exchanger consists of pipes that are aligned and placed separately from the furnace (Susana, 2018). The biomass energy is often used in the dryer with the natural convection method and produces hot air at a temperature of $50^{\circ} \mathrm{C}$ (Bhuyan et al., 2016). Preliminary research compared forced convectional solar dryer with natural convection, in a designed collector area of $2 \mathrm{~m}^{2}$ to dry chillies and grapes (Sushrut et al., 2015). This forced convectional solar dryer was discovered to be better in terms of drying speed and quality. Furthermore, another experimental study was carried out on solar dryers, equipped with sun tracking to dry apple slices over a temperature range of $62^{\circ} \mathrm{C}$ and $45^{\circ} \mathrm{C}$ (Das and Akpinar, 2020). The disadvantage of this process is its weather-dependent, thereby being unable to maintain continuous drying. The utilization of renewable energy such as biomass and the application of heat exchangers aforementioned is used to solve conventional agricultural and post-harvest problems. This is because conventional agriculture is dependent on weather and climate. Furthermore, the heat exchanger uses the hot air from the burning biomass in the furnace for the drying process. This device is used to transmit heat between two fluids separated by a wall and at different temperatures (Incropera et al., 2006). Biomass, which is an organic characteristic, derived from living organisms namely plants, animals, and agricultural wastes is an effective substitute for fossil energy.

Concerning biomass resources, Indonesia has great potential for this type of renewable energy, particularly rice husk as a rice waste product. Additionally, rice serves as a food source for most people with the expectation of fulfilling energy sources, carried out in rural areas through the energy conversion process such as gasification and pyrolysis. The gasification technological constitutes of $30 \%$ energy conversion used to produce 49.5 MWh of electrical energy (Pujotomo, 2017). Some of the location in Indonesia with the potential of biomass energy is West Nusa Tenggara and Lombok Island produce 533,150.80 and 269,420.20 tons of rice husks, respectively. It is estimated to produce sufficient energy to support a power capacity of 60 to 65 MW (RUED Provinsi Nusa Tenggara Barat, 2019; KPMG, 2019). Rice husk has a high heating value which is equivalent to half of the coal, namely $12.3 \mathrm{MJ} / \mathrm{kg}$ (Awulu et al., 2018). Its composition includes bulk density of relatively 90 to $150 \mathrm{~kg} / \mathrm{m}^{3}$, lignin $(25 \%$ to $30 \%)$, cellulose $(50 \%)$, silica (15\% to $20 \%$ ), and moisture (10\% to $15 \%$ ) (Burhenne et al., 2013; Singh, 2018). It is also a byproduct of relatively $20 \%$ of rice weight and is properly used as an energy source.

* Corresponding author.Email: gedebawa@unram.ac.id 
This is due to the high composition of cellulose which tends to produce stable combustion. Biomass is used as fuel in the energy conversion process to dry rice husks at a net calorific value of 12 to $16 \mathrm{MJ} \mathrm{kg}$ (International Finance Corporation, 2017). Furthermore, it is usually used in rural households for cooking and offering warmth to livestock. Biomass is also considered waste pollution in the environment therefore, increased logistics factors and properties are needed to make rice husks a renewable energy source (Mofijur et al., 2019). The decline in the use of firewood as fuel due to rice husks decreases deforestation and maintains sustainability (Ahiduzzaman and Sadrul Islam, 2016). Meanwhile, the utilization of rice husks in a heat exchanger furnace offers an optimal drying process.

The furnace converts the stored energy in the rice husks to thermal energy. The addition of a heat exchanger in the furnace increases the air temperature in the drying chamber (Susana et al., 2019). This study utilized black steel pipe as a heat exchanger and rice husks as fuel. In the no-load condition, the average temperature in the drying chamber was approximately $72.79^{\circ} \mathrm{C}$. Meanwhile, rice husk has a combustion efficiency of $99.2 \%$ and exhibits low emissions, as well as fire stabilization (Chokphoemphun et al., 2019). This is based on the results of the test carried out on a rectangular fluidized bed combustor. It also has LHV and HHV values of $13.3 \mathrm{kcal} / \mathrm{kg}$ and $14.8 \mathrm{MJ} / \mathrm{kg}$, which were obtained based on the measurements carried out on a downdraft furnace for drying rice (Hung et al., 2018). Furthermore, a direct test was carried out using rice husks and firewood to boil two litres of water. The result showed that the time needed to boil $1 \mathrm{~kg}$ of rice husk in water is 15 minutes. However, the same quality of rice husk was also boiled for 21 minutes using $1.2 \mathrm{~kg}$ of firewood (Yahaya and Ibrahim, 2012). Heat exchange dryers using rice husk energy are particularly suitable for household-scale drying processes and in developing rural areas. In the Philippines, the furnaces fueled by rice husks and heat exchangers with triangular tubing are used in agricultural engineering standards (Philippine National Standard, 2015). Meanwhile, those with perforated walls and the addition of heat exchanger pipes arranged in parallel optimally transfers heat into the drying chamber (Susana et al., 2019). The test results showed that it took 58 minutes to reduce the moisture content of $4 \mathrm{~kg}$ of corn from $19 \%$ to $12 \%$.

The drying performance of jackfruit dodol using rice husk in Lombok is still carried out traditionally, by drying in the sun. However, according to an evaluation result based on the physical parameters, such as porosity, volume, pore size distribution, and texture, this process deteriorates the product quality by damaging its structure (Link et al., 2017). Therefore, based on the sensitivity of certain products, such as vegetables and fruits, the sun-drying process tends to impair its sensory and nutritional properties (Ochoa-Martinez et al., 2012). Furthermore, the high production of rice husks in Lombok Island serves as an energy source for drying food in rural households, which is optimally carried out using a dryer. This is performed to enhance the standard of living in these communities.

\section{MATERIALS AND METHODS}

This research was carried out based on the dryer design and the optimal temperature test from previous studies (Alit et al., 2020). The optimal temperature is obtained using a 1-inch diameter heat-transmitting pipe made of stainless steel material. An $800 \mathrm{~mm}$ x $500 \mathrm{~mm}$ x $500 \mathrm{~mm}$ furnace, with an iron plate material of $400 \mathrm{~mm}$ feet is placed separately from the drying chamber. The furnace wall consists of 468 holes at a distance of $1 \mathrm{~cm}$ and $5 \mathrm{~cm}$ respectively. The design of the Jackfruit dodol dryer is as shown in Fig. 1. The arrangement of the drying chamber comprises 4 shelves made of aluminum. The drying chamber is isolated using a $3 \mathrm{~mm}$ thick rubber material. Furthermore, it has a dimension of $600 \mathrm{~mm} \times 536$ $\mathrm{mm} \times 536 \mathrm{~mm}$ and the leg height is $400 \mathrm{~mm}$. $400 \mathrm{~mm}$ is the support height of the drying chamber, which is the distance between the floor and the bottom of the drying chamber.

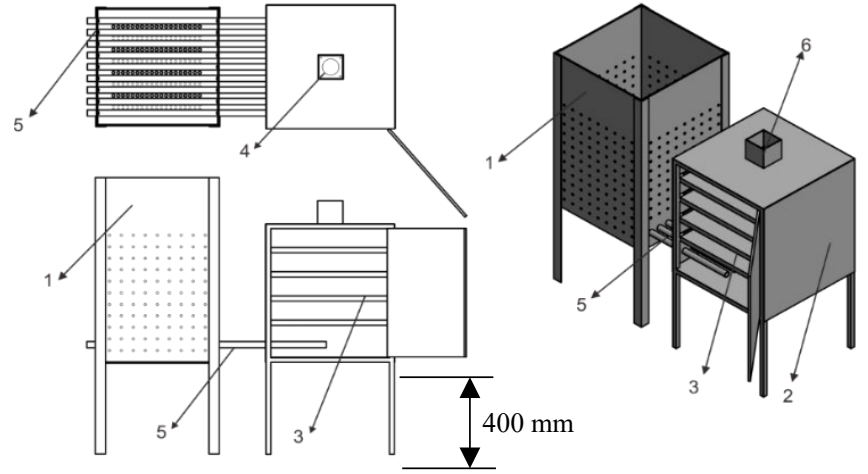

1. Furnace; 2. Drying chamber; 3. Drying shelves; 4. Exhaust fan; 5. Heat exchanger pipe; 6 . Chimney

Fig. 1 Rice husk dryer design

The dried product is $6 \mathrm{~kg}$ of jackfruit dodol. Also, $1.5 \mathrm{~kg}$ of this product was evenly distributed on each shelf. The initial moisture content of jackfruit dodol was set at $29 \%$. The drying chamber is equipped with a fan, located in the exhaust pipe or chimney. The air velocity constant is $2 \mathrm{~m} / \mathrm{s}$. The air velocity measurement of $2 \mathrm{~m} / \mathrm{s}$ is carried out on the exhaust fan which is placed in the chimney of the drying chamber. The performance of the dryer is based on the drying temperature and moisture content of jackfruit dodol. Therefore, this study was carried out using measuring instruments, such as data loggers, type K thermocouples, digital scales, anemometers, and moisture meters. The energy source is in the form of rice husks which transfers heat to the drying chamber through environmental air flowing in the pipes through combustion, as shown in Fig. 2.

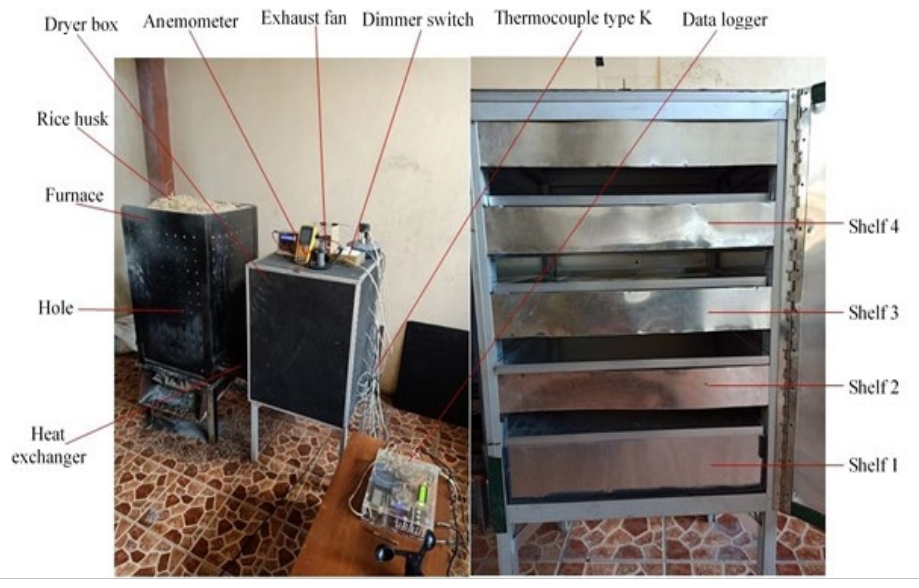

Fig. 2 Testing of jackfruit dodol samples on rice husk biomass dryer

The drying performance of jackfruit dodol was carried out for 600 minutes while the moisture content was measured every 60 minutes. The data measured includes ambient, entry, inner and outer temperatures in the drying room, as well as the initial, and dry mass of jackfruit dodol. The initial mass, $m_{t}(\mathrm{~kg})$ and dry mass, $m_{\mathrm{k}}(\mathrm{kg})$ is used to calculate the moisture content, $\mathrm{K}_{\mathrm{a}}(\%)$ (Henderson, 1976; Hamdani et al., 2018), as in Eq. (1). The heating procedure was carried out for 3 hours at a temperature of relatively 105 to $110^{\circ} \mathrm{C}$ to obtain the dry mass of dodol, $\mathrm{m}_{\mathrm{k}}$.

$K_{a}=\frac{m_{t}-m_{k}}{m_{t}} x 100 \%$

The mass of evaporated water, $m_{w}(\mathrm{~kg})$ is influenced by the initial mass $\left(\mathrm{m}_{\mathrm{t}}\right)$ of the jackfruit dodol, and the mass after drying $\left(\mathrm{m}_{\mathrm{p}}\right)$. Therefore, Eq. (2) is used to obtain the mass of evaporated water lost due to the drying process.

$m_{w}=m_{t}-m_{p}$ 
$\mathrm{m}_{\mathrm{p}}$ is the final mass of the material in each drying process. Obtained because each drying process will reduce the initial mass of the material due to the process of evaporation of water on the material or used to determine the mass of the material after the water has evaporated on material due to the drying process. While the dry mass $\left(\mathrm{m}_{\mathrm{k}}\right)$ was obtained by heating using an oven to the material until there was no weight loss with the treatment carried out at a temperature of $105-110^{\circ} \mathrm{C}$ for 3 hours.

The heat used for drying, Q (kJ) as in Eq. (3).

$Q=Q_{1}+Q_{2}$

$\mathrm{Q}_{1}$ is the quantity of heat used to dry the material of water $(\mathrm{kJ}) . \mathrm{Q}_{2}$ is the quantity of heat used to evaporate the moisture (kJ) (Hamdani et al., 2018; C Cengel and Boles, 2006). $\mathrm{C}_{\mathrm{pb}}$ is the quantity of specific heat applied to the jackfruit $\operatorname{dodol}\left(\mathrm{kJ} /{ }^{\circ} \mathrm{C}\right), \mathrm{Tb}$ is the jackfruit dodol temperature $\left({ }^{\circ} \mathrm{C}\right)$, Ta is the ambient temperature $\left({ }^{\circ} \mathrm{C}\right)$, and $\mathrm{h}_{\mathrm{fg}}$ is the latent heat of water evaporated $(\mathrm{kJ} / \mathrm{kg})$.

$Q_{1}=m_{t} \cdot C_{p b}\left(T_{b}-T_{a}\right)$

$Q_{2}=m_{w} \times h_{f g}$

$\rho_{\mathrm{u}}$ is the density of the drying air $\left(\mathrm{kg} / \mathrm{m}^{3}\right)$, while $C_{p u}$ is the specific heat of the air $\left(\mathrm{kJ} / \mathrm{kg} .{ }^{\circ} \mathrm{C}\right)$. The inner and outer temperatures of the air are $T_{\text {in }}$ and $T_{\text {out }}$, respectively. Therefore, the energy transfer from air to the dried material, $\mathbf{q}(\mathrm{kJ})$ is stated as follows (Incropera et al., 2006) as in Eq. (6).

$q=\rho_{u} \cdot V_{u} \cdot C_{p u}\left(T_{\text {in }}-T_{\text {out }}\right)$ Eq. (7)

The drying efficiency is as follows (Çengel and Turner, 2004) as in

$\eta=\frac{Q}{q} \times 100 \%$

The ratio of Eq. (2) to the drying time, $t$ (seconds) is the drying rate, $\dot{\mathrm{m}}_{\mathrm{p}}(\mathrm{kg} / \mathrm{s})$ (Brooker et al., 1992; Nazghelichi et al., 2010) as in Eq. (8).

$\dot{m}_{p}=\frac{m_{w}}{t}$

\section{RESULTS AND DISCUSSION}

The dried jackfruit dodol in this study is shown in Fig. 3 with initial moisture of $29 \%$ and a drying process of 600 minutes.

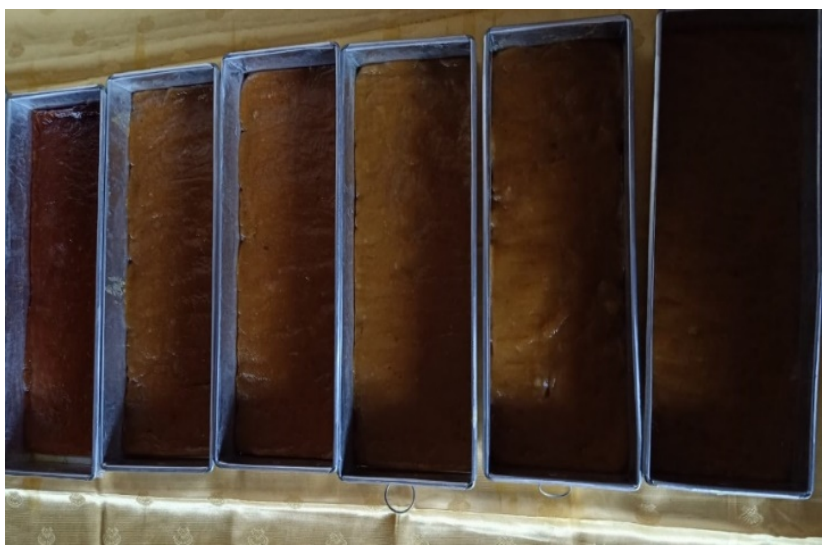

Fig. 3 The drying results of jackfruit dodol
Fig. 4 shows the temperature distribution that occurs in the jackfruit lunkhead drying process. The higher the temperature of the hot air that comes out of the heat exchanger pipes, the higher the drying temperature. The hot air is the input temperature (Tin) that is used to dry the jackfruit dodol in the drying chamber. The temperature distribution shown in Fig. 4 follows the process of burning the rice husks in the furnace. At the beginning of the combustion, the water content of the rice husk was evaporated. According to Mansaray and Ghaly (1997) that the moisture content of rice husks ranged from 8.68 to $10.44 \%$. Rice husks undergo a drying process before further heating occurs. This affects the temperature which has not increased significantly.

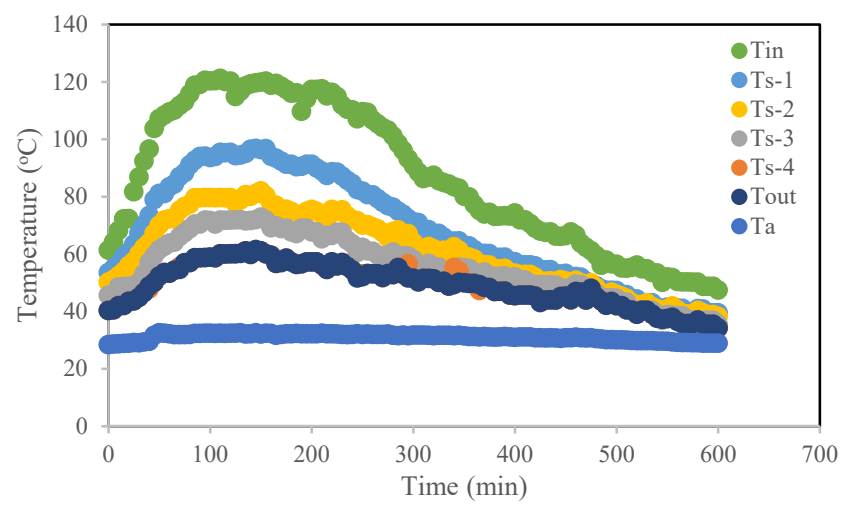

Fig. 4 Distribution of drying temperature

Rice husks are subjected to burning in the furnace starting from the bottom to the top. The combustion occurs due to the air flowing into the heat exchanger pipe and the drying room. The heat transfer from the burning of rice husk to the exchange pipe in the furnace occurs from the heat generated by the burning of rice husk outside the heat exchanger pipe which increases the surface temperature of the pipe. Then heat transfer occurs from a higher temperature heat exchanger pipe to the ambient air flowing in the pipe. Heat transfer in the drying chamber to the dodol occurs from the ambient air which initially flows into the heat exchanger pipe. This air absorbs heat from the heat exchanger pipes, then this hot air will flow into the drying chamber for the drying process. The utilization of environmental air as natural energy will reduce operating costs (Singh et al., 2019).

In the first 150 minutes, there was an increase in the temperature of the drying room (Tin). The average intake temperature (Tin) is $86.61^{\circ} \mathrm{C}$ which is within the range of 47.43 and $121.19^{\circ} \mathrm{C}$. The average ambient temperature (Ta) is $31.07^{\circ} \mathrm{C}$ within the range of 28.40 and $32.51^{\circ} \mathrm{C}$. The average exit temperature (Tout) is $49.14^{\circ} \mathrm{C}$ within the range of 34.23 and $61.49^{\circ} \mathrm{C}$. Furthermore, the combustion process spreads upward with the increase in time until all the rice husks are burned. On the other hand, there is a decrease in temperature when rice husks are burnt further away from the heat exchanger pipe, the temperature decreases. Generally, the temperature of the drying shelves (Ts) and the drying air (Tout) is based on the inner temperature (Tin). The temperature distribution in the drying chamber starts from the highest to the least namely shelves 1 (Ts-1), 2 (Ts-2), 3 (Ts-3), and 4 (Ts-4), respectively. The average temperature of shelf 1 (Ts-1) is $68.16^{\circ} \mathrm{C}$, which is within the range of 39.52 and $96.81^{\circ} \mathrm{C}$, while shelf 2 (Ts-2) is $60.76^{\circ} \mathrm{C}$ between 38.19 and $81.96^{\circ} \mathrm{C}$. Furthermore, the average temperature of shelf 3 (Ts-3) is $55.48^{\circ} \mathrm{C}$ within the range of 35.55 and $72.84^{\circ} \mathrm{C}$, while shelf 4 (Ts-4) is $49.28^{\circ} \mathrm{C}$ between 34.23 and $61.49^{\circ} \mathrm{C}$

The inner temperature of the drying chamber is uneven on each shelf due to the obstruction of hot air by the product arrangement and the lack of air passage to the overhead shelf. Also, the highest drying temperature occurred on shelf 1 because it is directly related to the heating source. This is consistent with the previous research carried out by Susana et al. (2020), which stated that the highest temperature occurred on shelf 1 in the drying chamber. Table 1 shows the data on temperature and mass change of jackfruit dodol which is measured every 60 minutes. 
Table 1 Dodol mass and temperature

\begin{tabular}{ccccccccccccc}
\hline $\begin{array}{c}\text { Time } \\
(\mathrm{min})\end{array}$ & Ta $\left({ }^{\circ} \mathrm{C}\right)$ & \multicolumn{4}{c}{ Drying chamber temperature $\left({ }^{\circ} \mathrm{C}\right)$} & \multicolumn{4}{c}{ Jackfruit dodol mass $(\mathrm{g})$} & \multicolumn{2}{c}{ Total } \\
& & Tin & Ts-1 & Ts-2 & Ts-3 & Ts-4 & Tout & ms-1 & ms-2 & ms-3 & ms-4 & mass \\
$(\mathrm{g})$
\end{tabular}

The period of 60 minutes is used to reduce the impact of the opening and closing processes of the chamber because it affects the temperature distribution process, which started decreasing in the 150 minutes. This is followed by the phenomenon of burning rice husks.

Fig. 5 shows the changes in the mass of jackfruit dodol on each shelf in the drying room after 600 minutes. Jackfruit dodol with an initial mass of $\pm 6,000$ grams (g) and moisture content of $29 \%$ was evenly distributed on each drying shelf $\pm 1,500 \mathrm{~g}$. The results showed that a longer drying time causes a decline in mass, which was rapid at the beginning of the process. The fastest reduction rate occurred on shelf 1 (ms-1) because it had a higher temperature than others. The decrease in mass on shelves 1 (ms-1), 2 (ms-2), 3 (ms-3), and 4 (ms-4) were approximately $8.8 \%, 7.2 \%$, $5.99 \%$, and $5.5 \%$ respectively. This decrease is based on the drying temperature distribution pattern with the least found on shelf 4 because the heat source is farther away from its position.

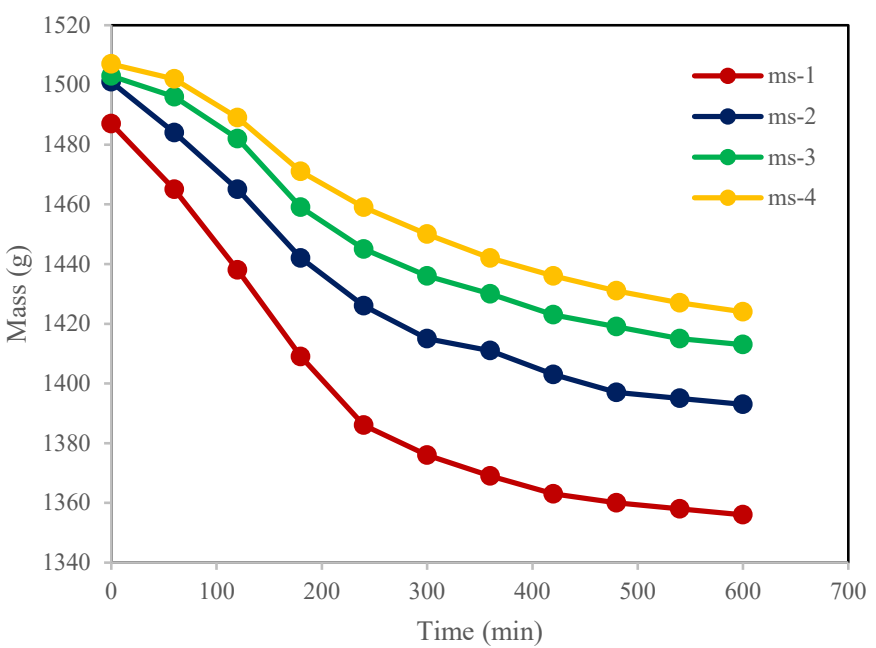

Fig. 5 Comparison of jackfruit dodol mass with the drying time on each shelf

Fig. 6 compares the use of rice husk biomass and the sun to dry the moisture. It showed that the use of rice husk dryers tends to reduce the moisture faster than the sun. Consequently, within 600 minutes, sun drying reduced the moisture content from $29 \%$ to $26.3 \%$. Meanwhile, therice husk biomass dryer was able to reduce the moisture from $29 \%$ to $23.7 \%$. Sun-drying to reach $23.7 \%$ jackfruit lunkhead water content takes \pm 3 days as shown in Fig. 7. This is caused by a very significant difference in drying temperature as shown in Fig. 8. Solar drying only utilizes ambient temperature, while drying in the drying chamber utilizes rice husk biomass which gives a higher temperature effect. The average drying temperature of the sun (Tsd) is $31.07^{\circ} \mathrm{C}$ while the average drying temperature of rice husk biomass (Tbd) is $58.42^{\circ} \mathrm{C}$.

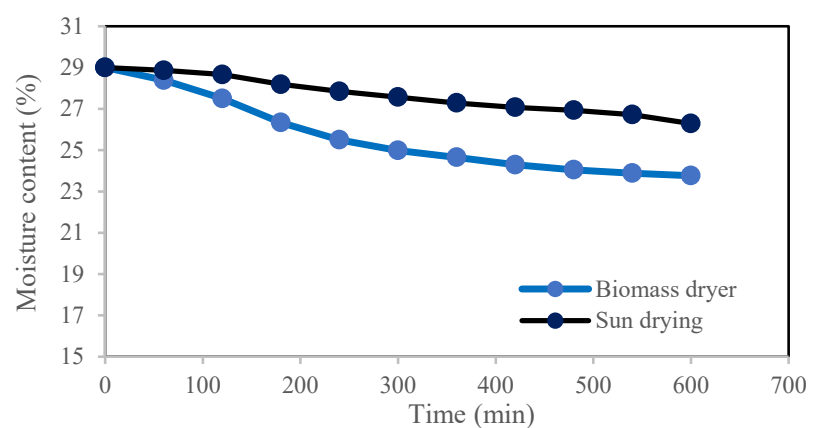

Fig. 6 Comparison of the sun and rice husk biomass used to dry the moisture content of jackfruit dodol

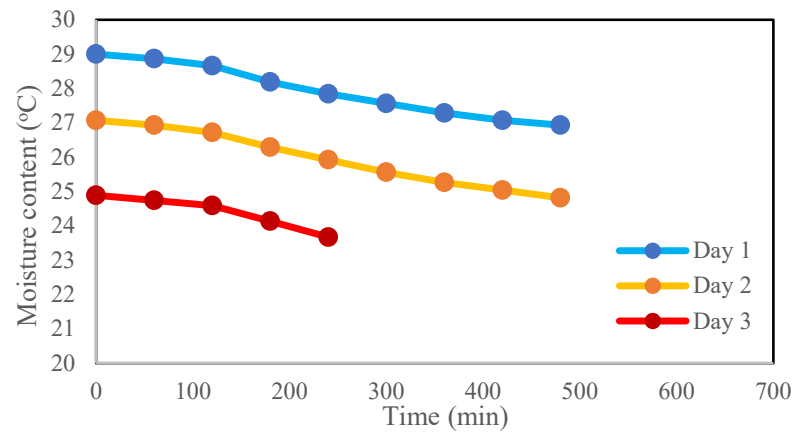

Fig. 7 Distribution of jackfruit dodol moisture content in the sun drying process

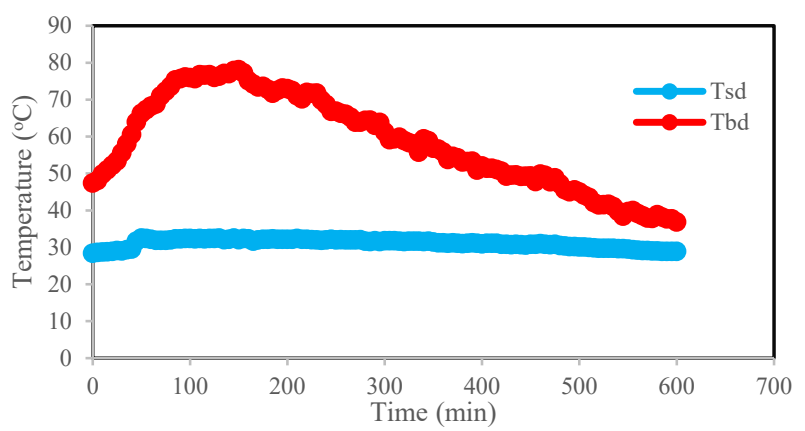

Fig. 8 Comparison of sun-drying temperature (Tsd) with rice husk biomass drying temperature (Tbd)

The rice husk biomass dryer decreased in moisture content by 0.687 $\mathrm{g} / \mathrm{min}$ with a chamber efficiency of $25.3 \%$. This condition is influenced by the drying temperature. The higher the drying temperature is directly proportional to the faster drying time and vice versa. Longer operating time is affected by lower temperatures (Bevington and Robinson, 2003). Besides, this is following the research of Waheed and Komolafe (2019); 
Dasore et al. (2020) which states that the reduction in drying time is due to an increase in temperature. Furthermore, rice husks as waste energy exhibit good results for drying food, as well as an alternative for the development of energy-efficient dryers (Djaeni et al., 2015). One kilogram of rice husks (calorific value $15 \mathrm{MJ} / \mathrm{kg}$ ) is capable of evaporates $4.5-5.0 \mathrm{~kg}$ of water vapour from paddy or shallots.

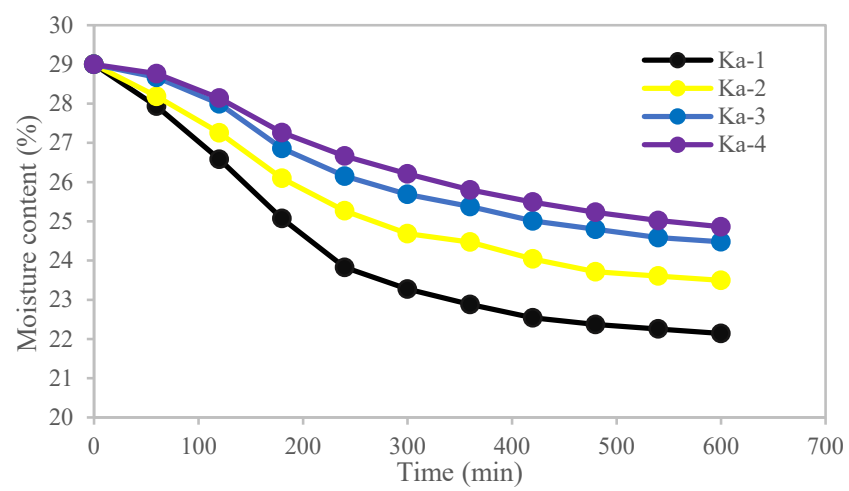

Fig. 9 Distribution of moisture content $(\mathrm{Ka})$ for each shelf in the drying chamber

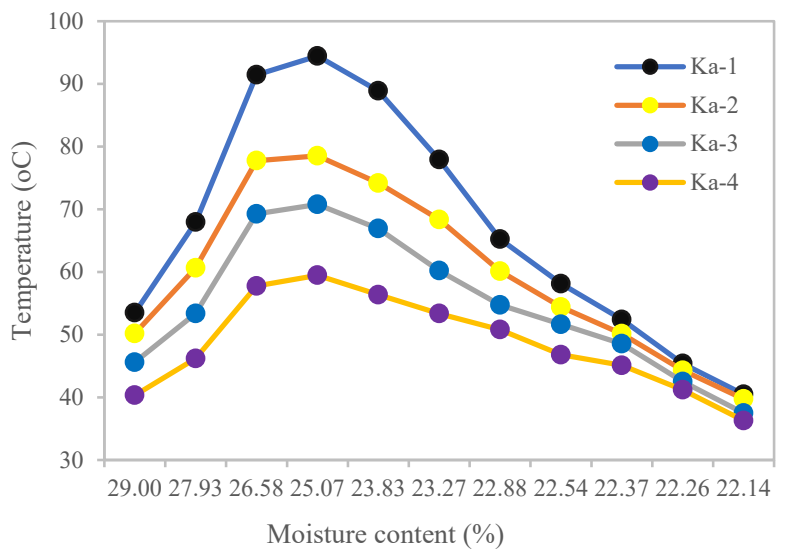

Fig. 10 Comparison of moisture content with temperature on each shelf

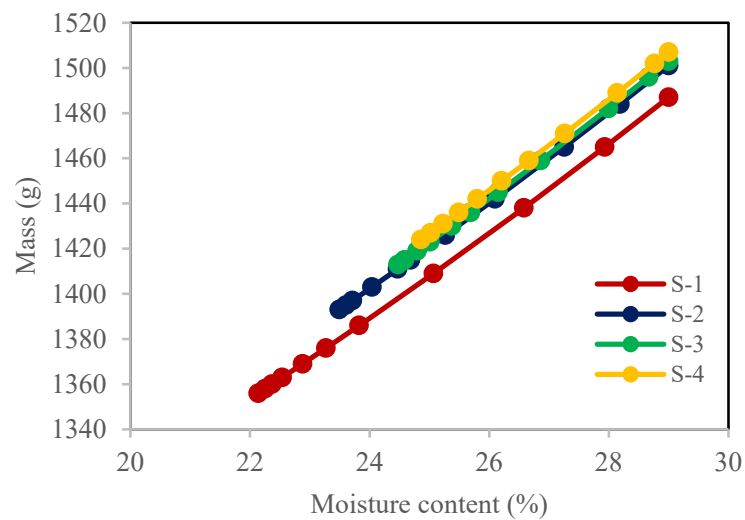

Fig. 11 Comparison of mass with moisture content on each shelf

Fig. 9 presents the distribution of moisture content with drying time for each shelf in the drying chamber. The fastest decrease in moisture contents to occur to the highest temperature conditions as shown in Fig. 10. This phenomenon occurs on the four shelves in the drying chamber. The decrease in water content was followed by a decrease in the mass of the material as presented in Fig. 11. The highest decrease in the mass of the material occurred on shelf 1 (S-1) then sequentially occurred on shelf 2 (S-2), shelf 3 (S-3), and the lowest occurred in shelf 4 (S-4). The fastest decrease in moisture contents occurs to shelf $1(\mathrm{Ka}-1)$ because it is closer to the drying input temperature. The farther away from the hot air source, the higher the moisture contents will be. The slowest decrease in moisture contents occurs to shelf $4(\mathrm{Ka}-4)$ because its position is farthest from the heat source.

Changes in the mass of jackfruit dodol are influenced by the disparity in drying temperature. This is in line with the research carried out by Alit et al. (2020), which stated that a decrease in the mass of the dried product is based on the temperature distribution. The dried product is more hygienic because it is carried out in the drying chamber. This study is in line with Delgado-Plaza et al. (2020) that drying products using a dryer minimises animal disturbance and rainy weather conditions compared to drying in the open sun. The dryer in this study was also designed to dry food ingredients other than jackfruit dodol. Based on the results of performance tests on jackfruit dodol, it is estimated that this dryer can be used to dry other agricultural products such as coffee, bananas, turmeric, chilli, and other post-harvest products for small farmers.

\section{CONCLUSIONS}

Rice husk is an energy-efficient fuel used for drying household products. In this research, rice husk was converted to thermal energy using the heat exchanger process, which is easy to operate and repair by the community. Based on the sample testing of $6 \mathrm{~kg}$ jackfruit dodol at a drying time of 600 minutes, the average drying chamber efficiency was $25.3 \%$. The dryer tends to reduce the moisture content of dodol from $29 \%$ to $23.7 \%$. The drying process using a biomass dryer is faster than the use of the sun in Lombok.

\section{ACKNOWLEDGEMENTS}

The authors wish to acknowledge DRPM for funding through the 2021 PTUPT research scheme with contract number 278/E4.1/AK.04.PT/2021 for the first year of research. The author also wishes to thank the Department of Mechanical Engineering, University of Mataram for facilitating the implementation of this research.

\section{NOMENCLATURE}

$C_{p b} \quad$ quantity of specific heat applied to the jackfruit dodol $\left(\mathrm{kJ} /{ }^{\circ} \mathrm{C}\right)$

$C_{p u} \quad$ specific heat of the air $\left(\mathrm{kJ} / \mathrm{kg} .{ }^{\circ} \mathrm{C}\right)$

$h_{f g} \quad$ latent heat of water evaporated $(\mathrm{kJ} / \mathrm{kg})$

$K_{a} \quad$ moisture content (\%)

$m_{k} \quad$ dry mass $(\mathrm{kg})$

$m_{p} \quad$ mass of after drying $(\mathrm{kg})$

$m_{t} \quad$ initial mass $(\mathrm{kg})$

$m_{w} \quad$ mass of evaporated water $(\mathrm{kg})$

$\dot{m}_{p} \quad$ drying rate $(\mathrm{kg} / \mathrm{s})$

$Q \quad$ heat used for drying $(\mathrm{kJ})$

$Q_{1} \quad$ quantity of heat used to dry the material of water $(\mathrm{kJ})$

$Q_{2} \quad$ quantity of heat used to evaporate the moisture (kJ)

$q \quad$ energy transfer from air to the dried material $(\mathrm{kJ})$

$T_{a} \quad$ ambient temperature $\left({ }^{\circ} \mathrm{C}\right)$

$T_{b} \quad$ jackfruit dodol temperature $\left({ }^{\circ} \mathrm{C}\right)$

$T_{\text {in }} \quad$ inner temperatures of the air $\left({ }^{\circ} \mathrm{C}\right)$

Tout outer temperatures of the air $\left({ }^{\circ} \mathrm{C}\right)$

$t \quad$ drying time (seconds)

Greek Symbols

$\rho_{u} \quad$ density of the drying air $\left(\mathrm{kg} / \mathrm{m}^{3}\right)$

$\eta \quad$ drying efficiency $(\%)$

\section{REFERENCES}

Ahiduzzaman, M. and Sadrul Islam, A.K.M., 2016, "Assessment of Rice Husk Briquette Fuel Use as an Alternative Source of Woodfuel", International Journal of Renewable Energy Research, 6(4), 1601-1611. 
Alit, I.B., Susana, I.G.B., and Mara, I.M., 2020, "Utilization of Rice Husk Biomass in the Conventional Corn Dryer Based on the Heat Exchanger Pipes Diameter", Case Studies in Thermal Engineering, 22, $1-9$.

https://doi.org/10.1016/j.csite.2020.100764

Awulu, J.O., Omale, P.A., and Ameh, J.A., 2018, "Comparative Analysis of Calorific Values of Selected Agricultural Wastes", Nigerian Journal of Technology, 37(4), 1141-1146.

http://dx.doi.org/10.4314/njt.v37i4.38

Bevington, P.R. and Robinson, D.K., 2003, Data Reduction and Error Analysis for the Physical Science, third ed., McGraw-Hill Companies.

Bhuyan, S.K., Rout, H. Pattanayak, B., and Mohapatra, S.S., 2016, "Performance Investigation of a Natural Convection Grain Dryer for Paddy Drying", International Journal of Renewable Energy Research, 6(3), 1050-1056.

Brooker, D.B., Bakker-Arkema, F.W., and Hall, C.W., 1992, Drying and Storage of Grain and Oilseeds, $4^{\text {th }}$ ed., Van Nostrad.

Buchori, L., Djaeni, M., and Kurniasari, L., 2013, "Upaya Peningkatan Mutu dan Efisiensi Proses Pengeringan Jagung dengan MixedAdsorption Dryer", Reaktor, 14(3), 193-198.

https://doi.org/10.14710/reaktor.14.3.193-198

Burhenne, L., Messmer, J., Aicher, T., and Laborie, M.P., 2013, "The Effect of the Biomass Components Lignin, Cellulose and Hemicellulose on TGA and Fxed Bed Pyrolysis", Journal of Analytical and Applied Pyrolysis, 101, 177-184.

https://doi.org/10.1016/j.jaap.2013.01.012

Cengel, Y.A. and Boles, M.A., 2006, Thermodynamics An Engineering Approach, $5^{\text {th }}$ ed., McGraw-Hill.

Çengel, Y.A. $\quad$ and Turner, R.H., 2004, Fundamental of Thermal-fluid Sciences, $2^{\text {th }}$ ed., McGraw-Hill Companies.

Chokphoemphun, S., Eiamsa-ard, S., and Promvonge, P., 2019, "Rice Husk Combustion Characteristics in a Rectangular Fluidized-Bed Combustor with Triple Pairs of Chevron-Shaped Discrete Ribbed Walls", Case Studies in Thermal Engineering, 14, 1-7. https://doi.org/10.1016/i.csite.2019.100511

Das, M. and Akpinar, E.K., 2020, "Determination of Thermal and Drying Performances of the Solar Air Dryer with Solar Tracking System: Apple Drying Test", Case Studies in Thermal Engineering, 21, 1-15. https://doi.org/10.1016/j.csite.2020.100731

Dasore, A., Polavarapu, T., Konijeti, R., and Puppala, N., 2020, "Convective Hot Air Drying Kinetics of Red Beetroot in thin Layers", Frontiers in Heat and Mass Transfer, 14(23), 1-8. http://dx.doi.org/10.5098/hmt.14.23

Delgado-Plaza, E., Quilambaqui, M., Peralta-Jaramillo, J., Apolo, H., and Velázquez-Martí, B., 2020, "Estimation of the Energy Consumption of the Rice and Corn Drying Process in the Equatorial Zone", Applied Sciences, 10(21), 1-21.

https://doi.org/10.3390/app10217497

Djaeni, M., Asiah, N., Suherman, S., Sutanto, A., and Nurhasanah, A., 2015, "Energy Efficient Dryer with Rice HuskFuelfor Agriculture Drying”, Int. Journal of Renewable Energy Development, 4(1), 20-24. http://dx.doi.org/10.14710/ijred.4.1.20-24

Hamdani, Rizal, T.A., and Muhammad, Z., 2018, "Fabrication and Testing of Hybrid Solar-Biomass Dryer for Drying Fish", Case Studies in Thermal Engineering, 12, 489-496.

https://doi.org/10.1016/j.csite.2018.06.008

Henderson, S.M. and Perry, R.L., 1976, Agricultural Process Engineering, The AVI Pub. Co., Inc., Westport, Connecticut.
Hung, N.V., Quilloy, R., and Gummert, M., 2018, "Improving Energy Efficiency and Developing an Air-Cooled Grate for the Downdraft Rice Husk Furnace", Renewable Energy, 115, 969-977. https://doi.org/10.1016/j.renene.2017.09.012

Incropera, F.P., DeWitt, D.P., Bergman, T., and Lavine, A., 2006, Fundamental of Heat and Mass Transfer, $6^{\text {th }}$ ed., John Wiley \& Sons, New York.

International Finance Corporation, 2017, Converting Biomass to Energy: A Guide for Developers and Investors, Pennsylvania Avenue, N.W. Washington, D.C.

KPMG, 2019, Lombok: Prefeasibility Studies on RE Solutions.

Link, J.V., Tribuzi, G., and Laurindo, J.B., 2017, "Improving Quality of Dried Fruits: A Comparison Between Conductive Multi-Flash and Traditional Drying Methods", LWT-Food Science and Technology, 84, 717-725.

https://doi.org/10.1016/i.lwt.2017.06.045

Mansaray, K.G. and Ghaly, A.E., 1997, "Physical and Thermochemical Properties of Rice Husk”, Energy Sources, 19(9), 989-1004. https://doi.org/10.1080/00908319708908904

Mofijur, M., Mahlia, T.M.I., Logeswaran, J., Anwar, M., Silitonga, A.S., Ashrafur Rahman, S.M., and Shamsuddin, A.H., 2019, "Potential of Rice Industry Biomass as a Renewable Energy Source", Energies, 12(21), 121 .

https://doi.org/10.3390/en12214116

Nazghelichi, T., Kianmehr, M.H., and Aghbashlo, M., 2010 "Thermodynamic analysis of fluidized bed drying of carrot cubes", Energy, 35(12), 4679-4684.

https://doi.org/10.1016/i.energy.2010.09.036

Nguimdo, L.A. and Noumegnie, V.A.K., 2020, "Design and Implementation of an Automatic Indirect Hybrid Solar Dryer for Households and Small Industries", International Journal of Renewable Energy Research, 10(3), 1415-1425.

Ochoa-Martinez, C.I., Quintero, P.T., Ayala, A.A., and Ortiz, M.J., 2012, "Drying characteristics of mango slices using the refractance window" technique", Journal of Food Engineering, 109(1), 69-75.

https://doi.org/10.1016/i.jfoodeng.2011.09.032

Philippine National Standard, 2015, Agricultural Machinery-Rice Husk Fed Heating System-Specifications, PNS/PAES 264.

Pujotomo, I., 2017, "Potensi Pemanfaatan Biomassa Sekam Padi untuk Pembangkit Listrik Melalui Teknologi Gasifikasi”, Energi dan Kelistrikan, 9(2), 126-135.

https://doi.org/10.33322/energi.v9i2

RUED Provinsi Nusa Tenggara Barat, 2019, Potensi Limbah Perkebunan untuk Biomassa, Peraturan Daerah Provinsi Nusa Tenggara Barat, No. 3.

Singh, B., 2018, "Rice husk ash", Waste and Supplementary Cementitious Materials in Concrete, 417-460.

https://doi.org/10.1016/B978-0-08-102156-9.00013-4

Singh, R., Mochizuki, M., Mashiko, K., and Nguyen, T., 2019, "Data Center Energy Conservation by Heat Pipe Based Pre-Cooler System", Frontiers in Heat and Mass Transfer, 13(24), 1-6. http://dx.doi.org/10.5098/hmt.13.24

Susana, I.G.B., 2018, "Improve of Worker Performance and Quality of Anchovy with Ergonomic Hybrid Solar Dryer", ARPN Journal of Engineering and Applied Sciences, 13(5), 1662-1667.

Susana, I.G.B., Mara, I.M., Okariawan, I.D.K., Alit, I.B., and Aryadi, I.G.A.K.C.A.W., 2019, "Ash Hole Variation in Rice Husk Biomass Furnace with Parallel Flow Heat Exchanger to Drying Box 
Temperature", ARPN Journal of Engineering and Applied Sciences, 14(2), 583-586.

Susana, I.G.B., Alit, I.B., and Mara, I.M., 2019, "Optimization of Corn Drying with Rice Husk Biomass Energy Conversion Through Heat Exchange Drying Devices", International Journal of Mechanical and Production Engineering Research and Development, 9(5), 1023-1032. https://doi.org/10.24247/ijmperdoct201991

Sushrut, S.H., Subbharpurmath, P., Havaldar, N., Hunashikatti, K., and Gokhale, S., 2015, "Experimental Analysis of Solar Air Dryer for Agricultural Products", International Research Journal of Engineering and Technology, 2(3), 1517-1523.
Waheed, M.A. and Komolafe, C.A., 2019, "Temperatures Dependent Drying Kinetics of Cocoa Beans Varieties in Air-ventilated Oven", Frontiers in Heat and Mass Transfer, 12(8), 1-7. http://dx.doi.org/10.5098/hmt.12.8

Yahaya, D.B. and Ibrahim, T.G., 2012, "Development of rice husk briquettes for use as fuel", Research Journal in Engineering and Applied Sciences, 1(2), 130-133.

Yunus, Y.M., Al-Kayiem, H.H., and Albaharin, K.A.K., 2011, "Design of a Biomass Burner/Gas-to-Gas Heat Exchanger for Thermal Backup of a Solar Dryer", Journal of Applied Sciences, 11(11), 1929-1936. https://doi.org/10.3923/jas.2011.1929.1936 